\title{
Spondylitis erosiva: report on 9 patients
}

\author{
I. JAJIĆ, Z. FURST, AND B. VUKSIC \\ From the Ward for Rheumatic Diseases of the Orthopaedic Hospital, the Medical Faculty of Zagreb and the \\ Institute of Radiology, Clinical Hospital Dr M. Stojanovic, Zagreb, Yugoslavia
}

SUMmaRY Nine patients ( 5 male and 4 female) are described with mild pain in the lumbar and thoracolumbar spine, early morning pain, morning stiffness, and moderately reduced mobility of the spine. Initial $x$-ray examination of the spine revealed sclerosis of one or several vertebral bodies and erosions in various parts of the vertebral bodies. In the further course of the disease squaring, sacroiliitis, and arthritis of the apophyseal joints was found. Seven of the 9 patients had the histocompatability antigen HLA B27. On the basis of these observations it is considered that 7 of these 9 patients had ankylosing spondylitis, the erosive lesions of the vertebral bodies being the first visible signs of the disease.

Erosive and destructive lesions of the vertebral bodies and discs are known to occur in ankylosing spondylitis. The opinion prevails that these lesions are a late manifestation of the disease. ${ }^{1-8} \mathrm{It}$ is, however, less well known that such changes may be an early and even the first radiological sign of ankylosing spondylitis. ${ }^{9-11}$ Particular attention has been paid to these changes with the aim of classifying them as a special group. ${ }^{12}$

\section{Patients and methods}

In the period 1975 to 1980 erosive lesions of the vertebral bodies were observed in 9 patients $(5$ men and 4 women, age range from 26 to 54 years).

A personal and family case history was taken and an extensive examination was made of the locomotor system, especially the spine. $X$-ray examinations were made of the spine (standard $x$-rays and tomography), scintigraphy was performed, and HLA antigens were determined.

The patients were observed for periods of 2 to 4 years. The Rome criteria were applied for the diagnosis of ankylosing spondylitis. ${ }^{11}$

\section{Results}

Clinical and radiological details are given in Tables 1 and 2. During the first interview it was established

\section{Accepted for publication 6 April 1981.}

Correspondence to Professor I. Jajić, 41000 Zagreb, Lovćenska 100 , Yugoslavia.
Table 1 Distribution patients according to sex, age ofonset, age of examination, clinical finding of the spine, and the sacroiliac joints

\begin{tabular}{|c|c|c|c|c|c|c|c|}
\hline Patients & $5 \mathrm{Sex}$ & $\begin{array}{l}\text { Age of } \\
\text { onset }\end{array}$ & $\begin{array}{l}\text { Age of } \\
\text { examination }\end{array}$ & Lordosis & Inclination & $\begin{array}{l}\text { Finger- } \\
\text { floor } \\
\text { distance } \\
(\mathrm{cm})\end{array}$ & $\begin{array}{l}\text { Breathing } \\
\text { index } \\
(\mathrm{cm})\end{array}$ \\
\hline 1 & $\mathbf{F}$ & 48 & 52 & reduced & $4 \cdot 5$ & 12 & $5 \cdot 0$ \\
\hline 2 & $\mathbf{F}$ & 39 & 41 & reduced & $4 \cdot 0$ & 20 & $6 \cdot 0$ \\
\hline 3 & $\mathbf{F}$ & 43 & 46 & normal & $4 \cdot 5$ & 5 & $7 \cdot 0$ \\
\hline 4 & $\mathbf{M}$ & 42 & 45 & reduced & $4 \cdot 5$ & 7 & $6 \cdot 5$ \\
\hline 5 & $\mathbf{F}$ & 34 & 37 & reduced & $2 \cdot 5$ & 18 & $4 \cdot 0$ \\
\hline 6 & $\mathbf{M}$ & 32 & 36 & normal & $5 \cdot 0$ & 20 & $8 \cdot 0$ \\
\hline 7 & $\mathbf{M}$ & 24 & 26 & normal & $4 \cdot 0$ & 0 & $9 \cdot 0$ \\
\hline 8 & $\mathbf{M}$ & 50 & 52 & reduced & $5 \cdot 0$ & 16 & $8 \cdot 0$ \\
\hline 9 & $\mathbf{M}$ & 40 & 43 & reduced & $5 \cdot 0$ & 13 & 5.0 \\
\hline
\end{tabular}

Table $2 \mathrm{X}$-ray finding of the spine, the sacroiliac joints, and the HLA B27 antigen

\begin{tabular}{|c|c|c|c|c|c|c|c|}
\hline \multirow[t]{3}{*}{ Patients } & \multicolumn{7}{|l|}{ Lesions } \\
\hline & \multirow[t]{2}{*}{ Squaring } & \multirow{2}{*}{$\begin{array}{l}\text { Syndesmo- } \\
\text { phytes }\end{array}$} & \multirow{2}{*}{$\begin{array}{l}\text { Affection } \\
\text { of the } \\
\text { apophy- } \\
\text { seal joints }\end{array}$} & \multirow{2}{*}{$\begin{array}{l}\text { Spondylitis } \\
\text { (erosions) }\end{array}$} & \multicolumn{2}{|c|}{ S Sacroiliitis } & \multirow{2}{*}{$\begin{array}{r}H L A \\
-B 27\end{array}$} \\
\hline & & & & & Right & Left & \\
\hline 1 & L1, L2 & - & - & L4, L5 & - & - & + \\
\hline 2 & L3 & + & - & L2, L3 & $1^{*}$ & 2 & + \\
\hline 3 & L4, L5 & - & - & L4, L5 & - & - & - \\
\hline 4 & - & - & - & L3 & - & - & - \\
\hline 5 & $\underset{\text { L5 }}{\mathrm{T} 12, \mathrm{~L} 1,}$ & - & - & L4, L5 & 2 & 3 & + \\
\hline 6 & L5 & - & - & L5, S1 & 1 & 2 & + \\
\hline 7 & T8-11 & - & - & T8-11 & 2 & - & + \\
\hline 8 & T11-L1 & - & $\mathrm{C} 2-\mathrm{C} 7$ & L1 & 1 & 2 & + \\
\hline 9 & - & - & - & $\mathrm{T} 12$ & 2 & 3 & + \\
\hline
\end{tabular}


that none of the patients had sustained any trauma. All of them had been complaining of back pain or low back pain of moderate intensity for 1 to 3 years. Two female patients complained of pain in the thorax which was aggravated on deep inspiration. Early morning pain and morning stiffness in the lumbosacral region were marked in 7 patients and lasted from 15 to 60 minutes.

Clinical investigation of the spine showed tenderness on palpation and pain on movement. Inclination, lateral flexion, and extension of the lumbar spine were reduced in 5 patients. The finger-floor distance was greater than $12 \mathrm{~cm}$ in 5 patients.

The HLA B27 antigen was found in 7 of our 9 patients. Erythrocyte sedimentation rate and blood count were within normal limits. $X$-rays of the sacroiliac joints showed early sacroiliitis in two patients. Destructive lesions of the vertebral bodies were present in all patients, most commonly in the lumbar spine. In 2 patients they were found in the thoracic spine (patients 7 and 9, Fig. 1) and in 1 patient in the sacrum (patient 6, Fig. 2). The fourth and fifth lumbar vertebrae were those most frequently involved.

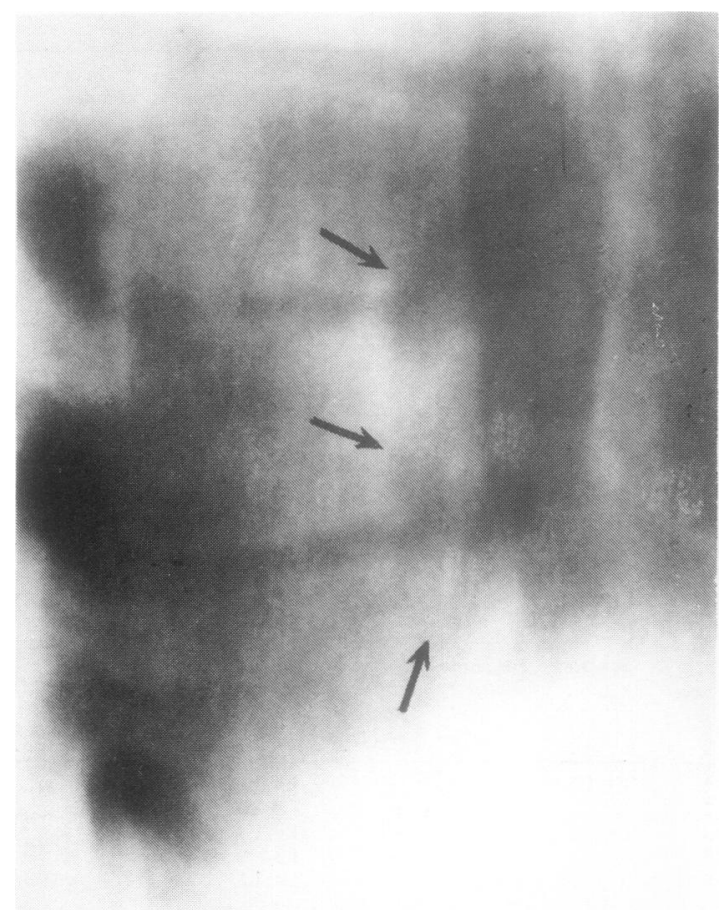

Fig. 1 Case 7. Sagital tomogram showing deep erosions of T8, T9, and T10. Widening of the T8-9 and T9-10 disc space.

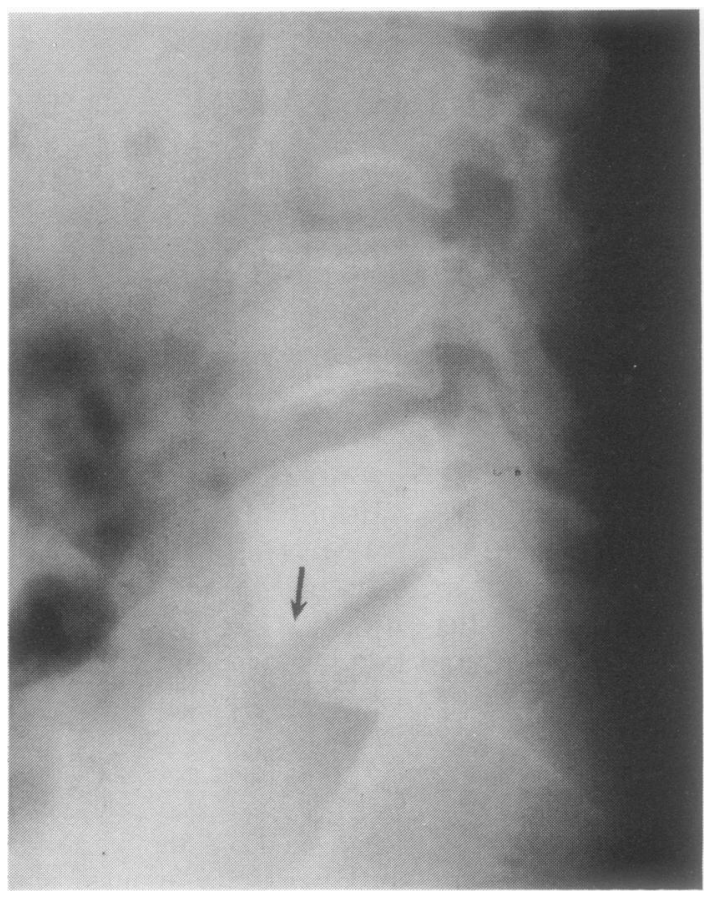

Fig. 2 Case 6. Lateral view showing lesions at the lower rim of L5 and upper rim of S1 with sclerosis of whole vertebral bodies.

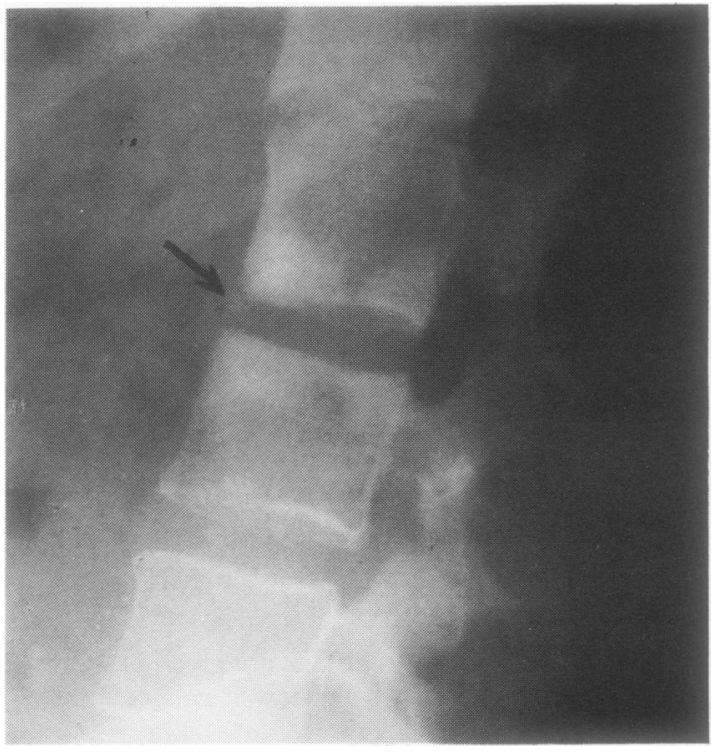

Fig. 3 Case 2. Squaring at the anterior and posterior rim of L3 and L4. Incomplete syndesmophyte (arrow). 

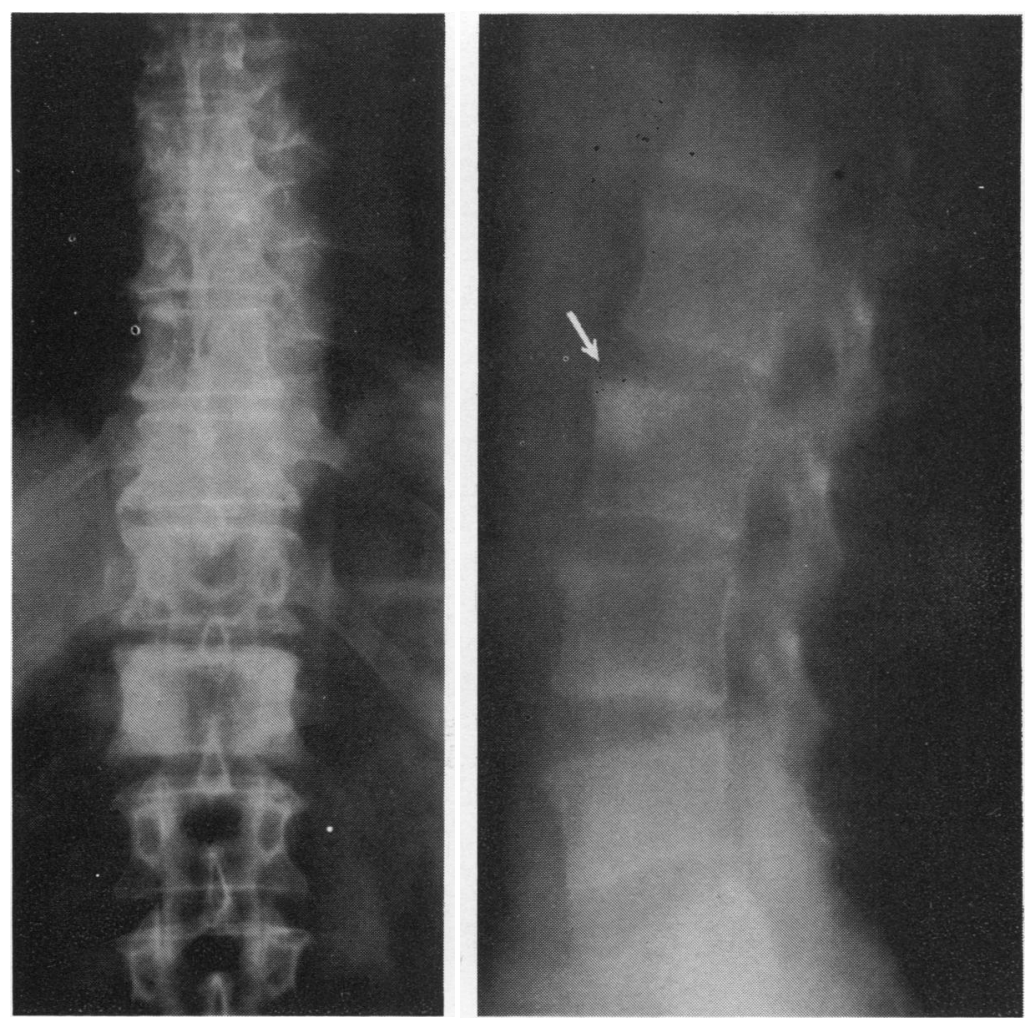

Fig. 4 (left) Case 8. Complete sclerosis in the body of L1. Sagital tomogram showed multiple lesions in the vertebral end-plates.

Fig. 5 (right) Case 4. Sagital tomogram showing deep erosion in the upper end-plates of $L 3$ with wide zone of sclerosis.

Standard $x$-rays of the spine, particularly lateral radiographs, revealed sclerosis of the corners of the vertebral body, most frequently involving the anterior corners (upper or lower), less often the posterior corners (patient 2, Fig. 3) or the entire vertebral body (patient 8, Fig. 4). In the lateral view the margins of the vertebral bodies were vaguely defined (Fig. 5). Tomography of the affected regions confirmed the presence of erosions and ulceration (Fig. 6 ). The intervertebral joints $\mathrm{C} 2-\mathrm{C} 7$ were affected in patient 8 . The remaining parts of the spine did not show any changes of ankylosing spondylitis. The intervertebral spaces were only slightly widened.

During prolonged observation other $x$-ray signs developed, characteristically associated with ankylosing spondylitis, such as squaring, syndesmophytes, and sacroiliitis, together with clinical signs (early morning low back pain, morning stiffness of greater intensity, restricted movement of the lumbar spine and thorax). Total restitution of the lesions was not seen. In patient 1 it was established that one of her 2 brothers was suffering from ankylosing spondylitis.

\section{Discussion}

The lesions described have been found in ankylosing spondylitis ${ }^{1-1417}$ and in osteoarthrosis of the spine. ${ }^{15}$ The pathogenesis of these lesions in ankylosing spondylitis is presumably inflammatory in nature..$^{916}$ In the later stages, the destructive lesions may be associated with trauma. ${ }^{9}$ Destructive lesions are said to be found less frequently in cases of ankylosing spondylitis when exercises of crawling are omitted from the physiotherapy programme. ${ }^{18}$

On the basis of the clinical findings, the course of the disease, the $x$-ray changes of the sacroiliac joints, the family history, and the finding of the antigen HLA B27 we conclude that 7 of our patients had ankylosing spondylitis (patients 1, 2, 5, 6, 7, 8, 9). The destructive lesions were precursors to other features of the disease and, in association with localised pain, were thought to signify the presence of a tumour (patient 2) or infection (patient 6). Two to 4 years elapsed before the onset of other symptoms such as spreading low back pain, early morning back pain, intensification of low back morning stiffness, and impaired movements of the spine and thorax. 


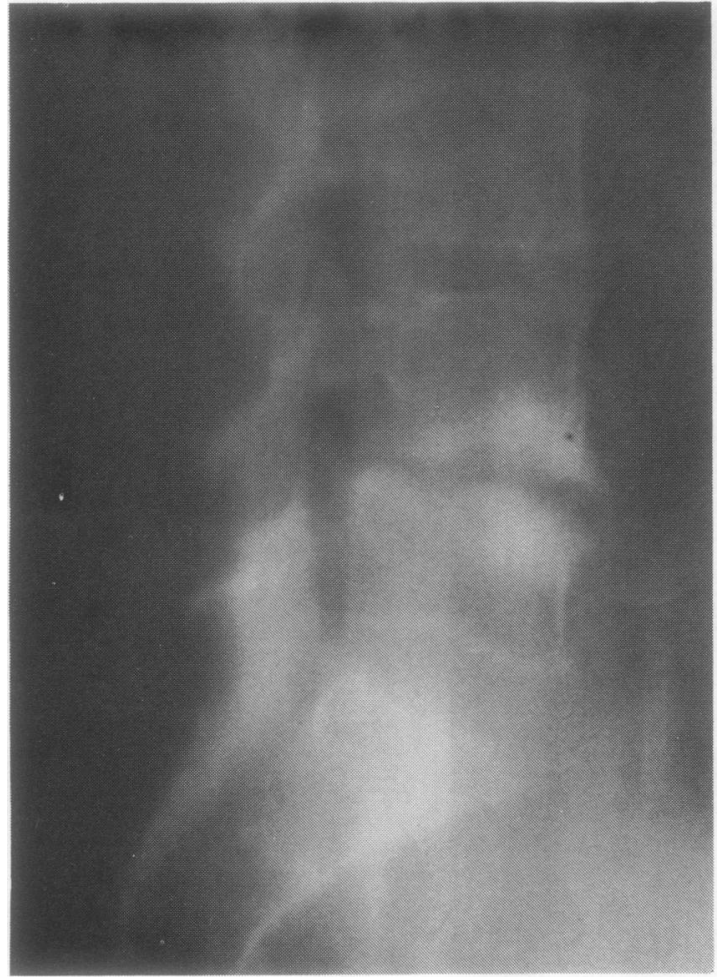

Fig. 6 Case 1. Sagital tomogram showing deep erosions in the lower end-plate of L4 and upper end-plate of L5 with associated sclerosis. Widening of the L4-L5 disc space with incomplete syndesmophyte.

In patient 3 , on the other hand, we believe that degenerative changes (Fig. 7) were present, while in patient 4 the nature of the disease process remains uncertain. In neither of these 2 patients was the HLA B27 antigen found.

Radiological and histological investigations by Dihlmann and coworkers ${ }^{19}$ support our opinion, since they show that the types of lesions described are associated primarily with inflammation or are a reflection of a combination between an inflammatory process and secondary degenerative changes. The lesions described do not differ from the 'destructive' lesions in established ankylosing spondylitis.

\section{Reterences}

1 Andersson $O$. Röntgenbilden vid spondylarthritis ankylopoetica. Nordisk Medicinisk Tidskrift 1937; 14: 2000-5.

${ }^{2}$ Louyot P, Gaucher A, Monthien J, Miquel G. La spondylodiscite de la spondylarthrite ankylosante. Rev Rhum Mal Osteoartic 1963; 30: 263-9.

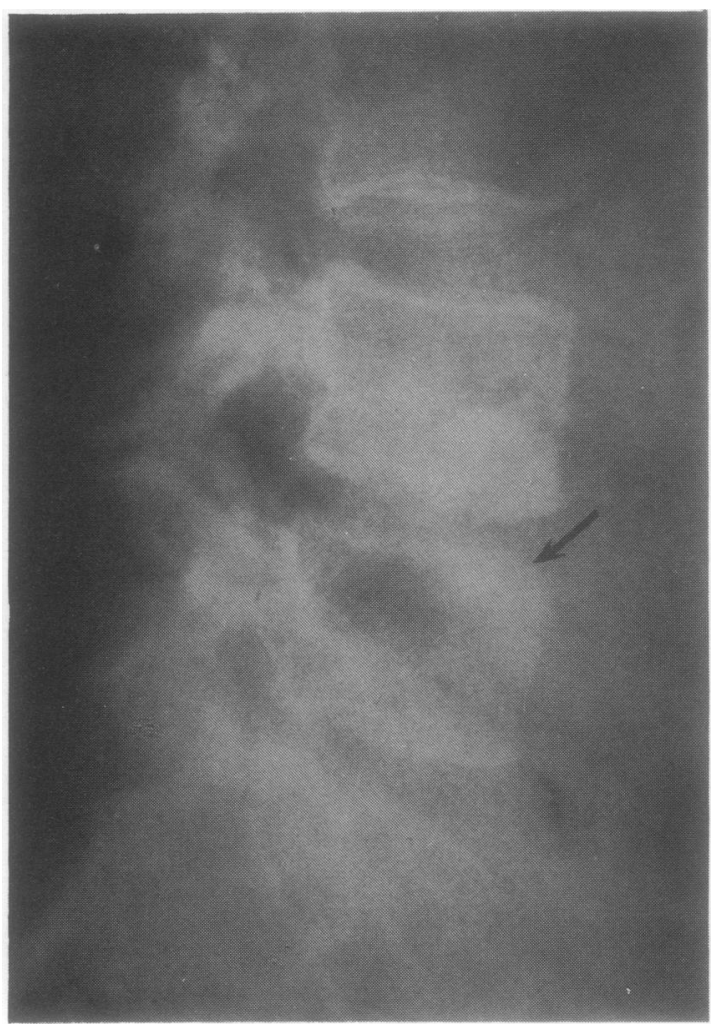

Fig. 7 Case 3. Lateral view of the lumbar spine showing deep lesion in the upper corner of L4 with neighbouring sclerosis and sclerosis in the body of L4.

${ }^{3}$ Forestier J, Jaqueline F, Rotes-Querol J. La Spondylarthrite Ankylasante. Paris: Masson, 1951.

4 Brocket J E W. Die Wirbelsäulenleiden und ihre Differentialdiagnose. 3rd ed. Stuttgart: Thieme, 1962.

5 Coste F, Delbarre F, Cayla J, Massias P, Beaslay E. Spondylitis destructives dans la spondylarthrite ankylosante. Presse Med 1963: 20: 1013-6.

- Durrigl T, Križ L. Spondylodiscitis u toku ankilozantnog spondilitisa. Reumatizam 1965; 12: 173-80.

7 Dihlmann W. Spondylitis ankylopoetica-die Bechterewsche Krankheit. Stuttgart: Thieme, 1968.

' Cawley M I D, Chalmers T M, Kellgren J H, Ball J. Destructive lesions of vertebral bodies in ankylosing spondylitis. Ann Rheum Dis 1972; 31: 345-58.

- Jajić I. Ankilozanti spondilitis. Skolska knjiga. Zagreb: 1978.

${ }^{10}$ Hicklin J A. Erosive vertebral disease in ankylosing spondylitis. Ann Physical Med 1968; 9: 206-8.

11 Little H, Urowitz M B, Smythe H A, Rosen P H. Asymptomatic spondylodiscitis. An unusual feature of ankylosing spondylitis. Arthritis Rheum 1974; 17: 487-93.

12 Courtois C, Fallet G H, Vischer T L, Wettstein P. Erosive spondylopathy. Ann Rheum Dis 1980; 39: 462-8.

13 Julkunen H. Rheumatoid Spondylitis. Helsinki: 1962.

${ }^{14}$ Berens D L Roentgen features of ankylosing spondylitis. Clin Orthop 1971; 74: 20-33. 
15 Lagier R, Guelpa G, Gerster J C. Lumbar erosive intervertebral osteochondrosis. ROEFO 1979; 130: 203-9.

${ }^{16}$ Bywaters E G L. Pathological and radiological development of the Romanus lesion in ankylosing spondylitis. Abstracta XII. Congressus rheum. internationalis. Praga: 1969.

${ }^{17}$ Wilkinson M, Bywaters E D L. Clinical features of course of ankylosing spondylitis as seen in follow-up of 222 hospital referred cases. Ann Rheum Dis 1958; 17: 209-28.

18 Susta A. Bechterevova ankylozujuci spondylartrida. Kompendium Lekarske posudkove cinnosti. Prague. 1964.

19 Dihlmann W, Delling G. Disco-vertebral destructive lesions associated with ankylosing spondylitis. Skeletal Radiology 1978; 3: $10-6$. 